LWSA

Local Wisdom, Social, and Arts

PAPER - OPEN ACCESS

\title{
Pendampingan Hukum Bagi Penyandang Disabilitas di Kota Medan dan Binjai
}

\author{
Author \\ : Rosmalinda Rosmalinda \\ DOI \\ : 10.32734/lwsa.v1i1.163 \\ Electronic ISSN \\ : 2654-7058 \\ Print ISSN \\ : 2654-7066
}

Volume 1 Issue 1 - 2018 TALENTA Conference Series: Local Wisdom, Social and Arts

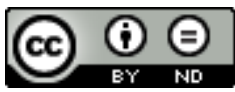

This work is licensed under a Creative Commons Attribution-NoDerivatives 4.0 International License.

Published under licence by TALENTA Publisher, Universitas Sumatera Utara
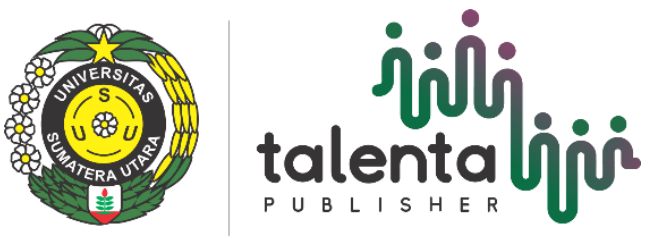


\title{
Pendampingan Hukum Bagi Penyandang Disabilitas di Kota Medan dan Binjai
}

\author{
Rosmalinda $^{\mathrm{a}}$, Arif ${ }^{\mathrm{a}}$, Ainul Mardiyah ${ }^{\mathrm{a}}$ \\ ${ }^{a}$ Fakultas Hukum, Universitas Sumatera Utara, Medan \\ rosmalinda@usu.ac.id, arifbsn@yahoo.com, ainul_mardiyah48@ymail.com
}

\begin{abstract}
Abstrak
Setiap orang adalah sama didepan hukum tak terkecuali penyandang disabilitas. Penelitian berjudul - Model Pendampingan Hukum Bagi Difabel (Orang Yang Berkebutuhan Khusus) Yang Berhadapan Dengan Hukum Di Kota Medan \& Binjaill didukung oleh DIKTI dalam Skim Penelitian Hibah bersaing. Peneliti berharap diakhir penelitian akan diperoleh informasi; Pertama, situasi penyandang Disabilitas mengakses layanan hukum yang tersedia di masyarakat. Kedua, persfektif Organisasi atau Lembaga penyedia layanan bantuan hukum bagi Penyandang Disabilitas.

Untuk memperoleh tujuan yang diharapkan penelitian dilakukan menggunakan metode normatif empiris. Peneliti melakukan pengumpulan peraturan hukum dan menganalisanya dilanjutkan dengan pengumpulan data lapangan melalui Wawancara mendalam dengan beberapa informan di Kota Medan dan Binjai.

Beberapa temuan awal penelitian memperlihatkan bahwa Kota Medan dan Binjai memiliki kasus pidana yang melibatkan penyandang disabilitas baik sebagai Pelaku, Korban dan Saksi. Tindak Pidana yang melibatkan penyadang disabilitas ini adalah Kekerasan seksual meliputi pelecehan seksual, perkosaan dan incest. Temuan lain penelitian adalah adanya kendala bagi Aparat Penegak Hukum dalam penanganan kasus yang melibatkan Penyandang Disabilitas ini.

Penelitian ini menyimpulkan bahwa dalam penanganan kasus hukum yang melibatkan penyandang disabilitas memiliki tantangan khusus terkait keterbatasan penyandan disabilitas. Tantangan tidak hanya dihadapi oleh penyandang disabilitas dan keluarga tetapi juga Aparat Penegak Hukum (APH).
\end{abstract}

Kata kunci: Pendampingan; Hukum; Disabilitas

\section{Pendahuluan}

Indonesia merupakan salah satu negara yang memposisikan hukum sebagai panglima. Ini berarti bahwa segala perbuatan yang dilakukan harus merujuk pada hukum yang mengaturnya sampai pada akhirnya hukum itu sendiri yang memberikan keadilan, kemanfaatan dan kepastian (Okidelfa, hal 17). Namun, bukan berarti segala yang tertera di dalam peraturan perundang-undangan mutlak harus diikuti, mengingat bahwa hakim dapat memutuskan perkara berdasarkan keyakinannya dengan melihat fakta-fakta persidangan.

Sebagai negara yang bermartabat, wujud kepedulian Indonesia terhadap penyandang disablititas yang merupakan kelompok minoritas ialah dengan meratifikasi perjanjian internasional Convention on The Rights of Person with Disabilities (Konvensi tentang hak-hak penyandang disabilitas) melalui Undang-Undang No. 19 tahun 2011 dan pada April 2016 lalu, Indonesia telah mengesahkan Undang-Undang Nomor 8 tahun 2016 tentang Penyandang Disabilitas.

Dalam konsideran Undang-Undang Nomor 8 tahun 2016 disebutkan bahwa Negara Kesatuan Republik Indonesia menjamin kelangsungan hidup setiap warga negara, termasuk para penyandang disabilitas yang mempunyai 
kedudukan hukum dan memiliki hak asasi manusia yang sama sebagai Warga Negara Indonesia dan sebagai bagian yang tidak terpisahkan dari warga negara dan masyarakat Indonesia merupakan amanah dan karunia Tuhan Yang Maha Esa, untuk hidup maju dan berkembang secara adil dan bermartabat. Sesungguhnya poin ini menegaskan bahwa semua manusia adalah sama tanpa terkecuali termasuk di dalam hukum. Dengan demikian, penyandang disabilitas pun berhak untuk mendapatkan pendampingan ketika ia berhadapan dengan hukum baik itu sebagai pelaku, korban maupun saksi. Berdasarkan hal tersebut, penelitian ini akan melihat secara empiris bagaimana pendampingan hukum terhadap penyandang disabilitas di dalam masyarakat khususnya di Kota Medan dan Binjai.

\section{Pembahasan}

Salah satu pembeda Convention on The Rights of Person with Disabilities dengan Konvensi Internasional yang terkait dengan perlindungan hak asasi manusia lainnya adalah luasnya tujuan, makna dan ruang lingkup perlindungan bagi disabilitas. Dilihat dari tujuannya, konvensi ini tidak hanya untuk memajukan, melindungi dan menjamin penyandang disabilitas untuk menikmati hak-hak asasi manusia dan kebebasan fundamental yang juga dapat dinikmati orang yang bukan difabel, tetapi lebih jauh dari itu mereka harus dapat menikmatinya secara penuh dan tanpa diskriminasi yang didasarkan disabilitas. Selain itu, konvensi ini juga bertujuan untuk meningkatkan penghormatan terhadap harkat dan martabat insani yang melekat pada setiap diri manusia tanpa pandang bulu (Rahayu Repindowaty Harahap dan Bustanuddin, hal 21).

Disabilitas merupakan suatu konsep yang terus berkembang dan merupakan hasil dari interaksi antara orang-orang dengan keterbatasan kemampuan dan sikap dan Iingkungan yang menghambat partisipasi penuh dan efektif mereka di dalam masyarakat berdasarkan kesetaraan dengan yang lainnya.

Convention on The Rights of Person with Disabilities menjamin negara peserta konvensi untuk mengambil langkah yang tepat dalam menyediakan akses bagi penyandang disabilitas terhadap bantuan yang mungkin mereka perlukan dalam melaksanakan kapasitas hukum mereka, seperti pendamping hukum, penerjemah bahasa, kondisi ruang persidangan yang aksesibel bagi mereka dan sebagainya, serta menjamin secara efektif akses penyandang disabilitas pada keadilan didasarkan atas kesamaan dengan yang lain, termasuk melalui pengakomodasian pengaturan yang berkaitan dengan prosedur dan kesesuaian usia, dalam rangka memfasilitasi peran efektif penyandang disabilitas sebagai partisipan langsung maupun tidak langsung, termasuk sebagai saksi, dalam semua persidangan, termasuk dalam penyiclikan dan tahap-tahap awal lainnya.

Sementara itu produk nasional, Undang-Undang No. 8 tahun 2016 tentang Penyandang Disabilitas, disamping menjabarkan hak-hak penyandang disabilitas yang harus dipenuhi dan dihormati, maka dalam pasal 19 menekankan peran Pemerintah dan Pemerintah Daerah dalam menyediakan bantuan hukum kepada penyandang disabilitas dalam setiap pemeriksaan pada setiap lembaga penegak hukum dalam hal keperdataan dan/atau pidana sesuai ketentuan peraturan perundang-undangan. Dengan demikian jelas bahwa sudah ada pengaturan yang tegas bahwasannya wajib untuk memberikan bantuan hukum bilamana penyandang disabilitas berkonflik dengan hukum. Dengan dibuatnya peraturan ini, harusnya Pemerintah maupun Pemerintah Daerah sudah siap dengan segala instrument dan perangkat yang dibutuhkan bilamana yang berhadapan dengan hukum itu seorang disabilitas, sehingga tidak ada alasan untuk mengabaikan penyandang disabilitas.

Pendampingan hukum merupakan salah satu upaya yang bertujuan untuk menjamin dan memenuhi hak bagi masyarakat penerima bantuan hukum (yang dalam hal ini penyandang disabilitas) untuk mendapatkan akses keadilan, mewujudkan hak konstitusional segala warga negara sesuai dengan prinsip persamaan kedudukan di dalam hukum. Pendampingan hukum dapat dilakukan oleh organisasi bantuan hukum, organisasi bantuan hukum disabilitas, lembaga swadaya masyarakat dan lainnya yang dapat mengerti dan memahami kondisi yang bersangkutan.

Dalam melakukan pendampingan hukum terhadap seorang disabilitas, sering sekali terdapat hambatan sehingga proses pendampingan tidak berjalan lancar. Salah satu kendala yang sering dihadapi dalam proses pendampingan ialah sulitnya berkomunikasi dengan yang bersangkutan meskipun komunikasi telah dilakukan oleh orang-orang yang memahami kondisinya begitu juga dengan penerjemah. Hal ini dikarenakan kondisi emosional dan rasa dari penyandang disabilitas sering berubah-ubah, sehingga sulit untuk mengetahui keadaan yang bersangkutan seutuhnya. 
Berkaitan dengan pendampingan hukum bagi penyandang disabilitas, secara empiris peneliti melakukan wawancara mendalam dengan informan terkait kasus-kasus yang dihadapi oleh penyandang disabilitas. Berdasarkan temuan awal, Kota Medan dan Binjai memiliki kasus pidana yang melibatkan penyandang disabilitas baik sebagai Pelaku, Korban dan Saksi. Kasus Pidana yang terjadi adalah Kekerasan seksual seperti pelecehan seksual, perkosaan dan incest.

Salah satu temuan peneliti ialah kasus pelecehan seksual terhadap anak perempuan usia 5 (lima) tahun yang dilakukan oleh seorang tuna grahita-keadaan fungsi intelektual umum bertaraf subnormal yang dimulai dalam masa perkembangan individu dan yang berhubungan dengan terbarasnya kemampuan belajar maupun penyesuaian diri proses pendewasaan individu tersebut atau kedua-duanya (Arif Muttaqin, hal 426)-berusia 16 (enam belas) tahun. Berikut kronologi kasusnya berdasarkanWawancara dilakukan dengan Pak Mamat (Nama disamarkan):

"Pada tahun 2014 Pelaku dan keluarga liburan ke tempat pemandian wisata. Di tempat pemandian, Pelaku bermain dan bercanda sambil memeluk seorang ibu dan si ibu tidak marah, karena menyadari keadaan Pelaku yang tidak seperti anak normal. Kemudian, selang beberapa waktu Pelaku bermain lagi dan memeluk seorang anak perempuan berumur 5 tahun yang mengakibatkan anak itu menangis hingga terdengar kedua orang tuanya. Melihat kejadian itu, orang tua dari pihak korban melaporkan perbuatan Pelaku sebagai pelecehan seksual ke POLRES terdekat. Pihak POLRES menerima laporan dan memeriksa, pihak keluarga Pelaku menerangkan bahwa Agus adalah anak penyandang disabilitas, tunagrahita dan apa yang dilakukannya itu adalah tanpa ia sadari dan mengerti. Pihak POLRES menerima keterangan, namun pihak korban tetap tidak terima dan percaya. Kemudian meminta surat keterangan psikiater tentang keadaan Pelaku. Pihak Pelaku kemudian meminta data ke Sekolah dimana Pelaku sedang bersekolah saat itu. Namun pihak korban tetap tidak menerima dengan alasan belum cukup kuat dan tetap menuntut surat keterangan psikiater. Selang beberapa waktu, pihak korban kembali menuntut ganti rugi senilai 4 juta rupiah kepada pelaku untuk tanda selesai perkara dan damai. Proses "tawar menawar" perdamaian terus terjadi antara keluarga Korban dan Keluarga Pelaku. Hingga akhirnya, persoalan ini tidak terhenti tanpa penjelasan status hukum lebih lanjut.”

Kasus lain yang ditemukan oleh Tim Peneliti diperoleh dari Lembaga Swadaya Masyarat yang konsern dengan persoalan anak dan Perempuan. Berdasarkan hasil wawancara Penelitidengan staf Pendamping hukum diketahui bahwa kasus terjadi pada seorang anak berusia 3 tahun yang memiliki kedua orang tua penyandang disabilitas, tuna netra, pelaku adalah pegawai di panti Pijat milik kedua orang tua anak tersebut yang juga penyandang disabilitas. Kejadian ini dilaporkan orang tua korban kepada Pusat Kajian dan Perlindungan Anak (PKPA), namun kasus tidak berlanjut dikarenakan orang tua korban menemukan hambatan untuk mobilisasi ke PKPA.

Berdasarkan kasus yang ditemukan Peneliti, terlihat bahwa proses pendampingan Hukum sulit dilakukan bilamana penyandang disabilitas menjadi pihak yang berhadapan dengan hukum.

Hasil penelitian memperlihatkan lima faktor penyebab gagalnya proses pendampingan hukum bagi penyang disabilitas

1. Keterbatasan keahlian Aparat Penegak Hukum seperti Polisi dan Advokat dalam berkomunikasi dengan penyandang Disabilitas.

2. Adanya asumsi bahwa proses hukum membutuhkan biaya yang tinggi

3. Keterbatasan mobilitas dikarenakan biaya transportasi yang minim

4. Keterbatasan SDM dan anggaran yang tersedia pada lembaga Pendamping hukum

5. Adanya Pihak keluarga yang masih mengabaikan pentingnya pendampingan hukum bagi disabilitas

Kelima hal diatas merupakan faktor terhambatnya penanganan kasus yang melibatkan penyandang disabilitas meskipun sudah dilaporkan ke pihak Kepolisian. Lebih lanjut, kasus ini menjadi gambaran bagaimana sulitnya proses pendampingan hukum bagi penyandang disabilitas.

\section{Penutup}

Konvensi internasional maupun produk nasional menjamin pengambilan langkah yang tepat dalam menyediakan akses bagi penyandang disabilitas terhadap bantuan yang mungkin mereka perlukan dalam melaksanakan kapasitas 
hukum serta adanya kewajiban bagi Pemerintah dan Pemerintah Daerah untuk memberikan bantuan hukum bagi penyandang disabilitas.

Pendampingan hukum dilakukan untuk menjamin dan memenuhi hak bagi masyarakat penerima bantuan hukum (yang dalam hal ini penyandang disabilitas) untuk mendapatkan akses keadilan, mewujudkan hak konstitusional segala warga negara sesuai dengan prinsip persamaan kedudukan di dalam hukum. Namun, berdasarkan temuan lapangan, pendampingan hukum bagi penyandang disabilitas masih terdapat kendala yang menyebabkan pendampingan tidak berjalan lancar hingga mengalami kevakuman antara lain komunikasi yang tidak lancar, terbatasnya SDM dan anggaran yang mampu melayani penyandang disabilitas, sampai kepada pihak keluarga yang masih mengabaikan pentingnya pendampingan hukum bagi penyandang disabilitas.

\section{References}

[1] Harahap, Rahayu Repindowaty dan Bustanuddin, Januari 2015, Perlindungan Hukum Terhadap Penyandang Disabilitas Menurut Convention On The Rights Of Persons With Disabilities (CRPD), Jurnal Inovativ, Volume VIII Nomor I.

[2] Muttaqin, Arif, 2008, Asuhan Keperawatan Klien dengan Gangguan Sistem Persarafan, Salemba Medika, Jakarta.

[3] Yanto, Oksidelfa, 2010, Mafia Hukum :Membongkar Manipulasi dan Konspirasi Hukum di Indonesia, Raih Asa Sukses (Penebar Swadaya Grup), Jakarta.

[4] Convention on The Rights of Person with Disabilities.

[5] Undang-Undang Nomor 8 tahun 2016 tentang Penyandang Disabilitas, Lembaran Negara Republik Indonesia Tahun 2016 Nomor 69 , Tambahan Lembaran Negara Republik Indonesia Nomor 5871 